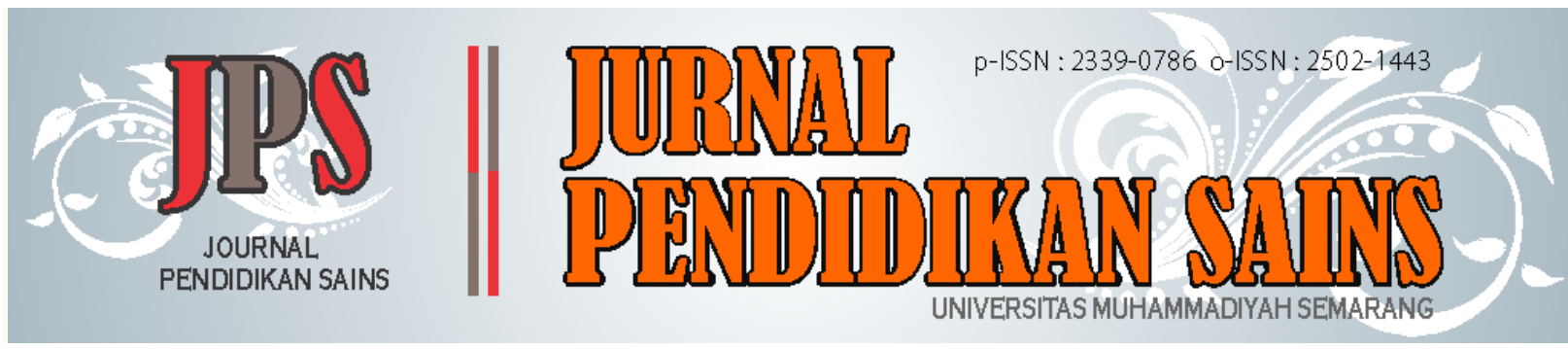

\title{
The Influence of Quantum Teaching and Learning (QTL) Model on Interests and Learning Outcomes of Chemistry
}

\author{
Uswatun Hasanah $^{1 *}$, Agus Kamaludin ${ }^{2}$ \\ ${ }_{1,2}$ Chemistry Education, Faculty of Education and Teaching Science, State Islamic University (UIN) Sunan Kalijaga, Yogyakarta \\ 1 aguskamaludin@gmail.com* \\ * corresponding author
}

\begin{tabular}{|c|c|}
\hline Article history & \multirow{9}{*}{$\begin{array}{l}\text { This research examines the effect of using the Quantum Teaching and } \\
\text { Learning (QTL) model on students learning interests and outcomes on } \\
\text { compound nomenclature material. The research was conducted in State } \\
\text { Senior High School } 8 \text { Yogyakarta in the 10th grade of mathematics and } \\
\text { natural science in 2018/2019. This type of research was Quasi-Experimental } \\
\text { Research Design with Nonequivalent Control Group Pretest and Posttest } \\
\text { Design. The sampling technique was purposive sampling. The data collection } \\
\text { instruments included interest questionnaires, pre-test, and post-test results. } \\
\text { The analyzed technique on students learning interest using the Mann Whitney } \\
\text { test because the data are abnormal distributed and learning outcomes using } \\
\text { Independent T-Test. Based on the statistical tests, the result showed a sound } \\
\text { effect of using Quantum Teaching and Learning (QTL) models influence the } \\
\text { interest and learning outcomes of chemistry with experimental class getting } \\
\text { learning outcomes was above } 80 \text {. }\end{array}$} \\
\hline$: 2021-02-21$ & \\
\hline : 2021-03-29 & \\
\hline Accepted & \\
\hline Keyword & \\
\hline Learning interests & \\
\hline Learning Outcomes & \\
\hline Teaching & \\
\hline Learning (QTL) model & \\
\hline
\end{tabular}

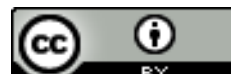

This work is licensed under

a Creative Commons Attribution 4.0 International License C2021 Jurnal Pendidikan Sains Universitas Muhammadiyah Semarang

\section{INTRODUCTION}

The success of an educational process can be seen from learning outcomes well achieved by the students (Mahirah, 2017). The quality of learning outcomes is tightly related to students' learning interests (Slameto, 2003: 57). The reason is that a good interest in learning will influence students to study harder, and it will influence the implementation process without any coercion (Soleh, Pramono, \& Suratno 2009). Engaging learning can raise students' interest in learning to carry out the learning process well if their interest has been grown (Aritonang, 2008). However, in reality, it is not uncommon for educators to use a learning model that has not been appropriate for students' characteristics so that it brings out boredom for students in pursuing the learning process; the material is difficult to be understood; and the learning process becomes monotonous so that students are less interested in learning (Wijanarko, 2017). The existence of boredom and lack of interest in learning are the factors that make students' learning outcomes weak (Maesaroh, 2013).

Students' achievement on learning outcomes is still low because the unappropriated learning process is very influential on subjects that are considered difficult (Saenab, Nurhayati, Hamka, \& Fitri, 2016). One of the courses of study that is considered difficult is chemistry (Supardi \& Putri, 2010: 574). 
The difficulty of chemistry relates to the characteristics of chemistry mentioned by Kean and Middlecamp in Rumansyah (2002: 172). Most chemistry is abstract and is a simplification of the actual science; the science development is fast; chemistry does not just solve questions, and the burden, of course, to be studied in learning chemistry is very much. Many chemistry courses that are considered abstract make chemistry one of the fields of science that students do not like. It causes an inability to connect between the sub-microscopic and macroscopic (Ristiyani \& Bahriah, 2016).

The chemistry course which is considered problematic by the students is chemical nomenclature (Maslukhah, 2014). The chemical nomenclature subject is considered difficult because the course feature is theoretical and memorizing, so that many students get weak learning outcomes (Manurung, Mulyani, Saputro, 2013). Based on the result of Pasaribu's (2013) research at State Senior High School 3 Jakarta, learning outcomes in the chemical nomenclature is still low at around $32.5 \%$. One of the causes of the low learning outcomes is that the learning presented cannot provide well understanding for students. They tend to be passive, lack interest in participating in learning and feeling saturated. Therefore it is necessary to use a more attractive model so that the chemical nomenclature subject is easy to be understood (Ismawati \& Hindarto, 2011). One of the alternative learning models used is Quantum Teaching and Learning(QTL) because it emphasizes fun learning. It can assist students in developing their interests to keep on learning enthusiastically (Djalil, 2015). Besides, Quantum Teaching Learning (QTL) can make students easier and more focused in understanding the material presented so that learning runs actively and effectively. The Quantum Teaching Learning (QTL) model can affect improving student achievement, cognitive competence, and student motivation (Sholikhah, 2017; Trisnawati \& Wutsqa, 2015; Haerudin \& Prawiyogi, 2019; Rizka \& Pratama, 2018; Fayanto, Musria, Erniwati, Sukariasih, \& Hunaidah, 2019).

Quantum Teaching and Learning(QTL) is an approaching model that emphasizes that learning must be delightful and take place in a happy environment. The entrance for information will be more comprehensive and well recorded. The QTL model was chosen because of its superiority with the TANDUR syntax (Sukerthi, Dantes, \& Yudana, 2013). TANDUR stands for (Tumbuhkan) Grow, (Alami) Experience, (Namai) Name, (Demonstrasikan) Demonstrate, (Ulangi) Repeat, and (Rayakan) Celebrate (Astuti, 2018). Grow (Tumbuhkan) is a concept that tries to invite and insert the thoughts and emotions of educators into students so that a sense of mutual understanding can be established. In general, this concept invites them in order to be interested and curious about the subject to be taught. It shows that a positive attitude at the beginning of learning needs to be given. Experience (Alami), this stage tries to synchronize between the subject being studied and students' direct experience that can be obtained through discussions with their friends. Name (Namai), this concept teaches how to train the thinking skills and learning strategies. It means that students have to conclude the subject according to their experiences. Demarcate (Demonstrasikan) is the stage in which the opportunity shows the level of students' understanding of the subject being taught and can be applied through educational games. Repeat (Ulangi), as a step to strengthen neural connections and memories, the educators can implement it by providing affirmations and asking questions or carrying out quiz. Celebrate (Rayakan), at this last stage, students who have understood the subject well will experience a sense of satisfaction and joy. Therefore the educators need to appreciate the success achieved by students (DePorter \& Hernacki, 2005: 10).

A conformable relation between the learning model and the subject being taught can raise and attract students' interest (Prihatini, 2017). Quantum Teaching and Learning(QTL), as one of the learning models, provides a stimulus for students' learning and provides its attractiveness in the learning process. Learning by applying the QTL model can foster students' interests. Their desire, willingness, and perseverance which are good at learning will provide good feedbackfor the learning outcomes which are obtained. A sense of comfort in learning is also one of the factors of success in learning. The Quantum Teafeedback foreign arning (QTL) model in learning, especially in chemical nomenclature subject, hopefully can help and make it easier for students to understand the subject and increase students' interests and learning outcomes. In addition, hopefully, study subjects initially, think that chemistry is a complex subject will realize it as an easy and delightful subject.

\section{METHOD}

\section{Type of Research}


This research is a quasi-experimental study using the Nonequivalent Control Group Pretest and Posttest Design.

\section{Time and Place of Research}

This research was conducted at State Senior High School 8 Yogyakarta in X grade of MIPA in the even semester of the 2018/2019 academic year. The research implementation started from February 4 , 2019, to February 18, 2019.

\section{Population and Sample of Research}

The population included all students of $\mathrm{X}$ grade of MIPA who were divided into seven classes with 223 people. The sample used was X grade of MIPA 5 (control class) and X grade of MIPA 1 (experimental class). The determination of the sample used the purposive sampling technique.

\section{Data Collection Technique}

The data collection technique applied in this study was conducted through interviews, documentation, questionnaires to determine students' interests in learning, and written tests (pre-test and post-test) to find out cognitive abilities.

\section{Data Analysis Technique}

The data analysis technique used for the interest questionnaire was the statistical test of Mann Whitney because the data which were obtained were not normally distributed. The pre-test and post-test data were tested using the Independent T-Test because the data obtained were usually distributed.

\section{RESULTS AND DISCUSSION}

This study used two learning models which were applied for two different classes. The experimental class used Quantum Teaching and Learning(QTL) model, while the control class used the Direct Instruction model. The research results obtained were in the form of interest questionnaire data and students' learning outcomes data.

\section{Study of The Effect of The Quantum Teaching and Learning (QTL) Model towards Students' Interests}

The questionnaire data analysis of students' interests was obtained by enumerating the total score gained from each practical aspect. Then, based on the results, the experimental class and the control class were compared. Based on these results, the average learning interest from each class was obtained. It is shown in Table 1.

Table 1. The Average Calculation Result of Interest Questionnaire

\begin{tabular}{lcc}
\hline \multicolumn{1}{c}{ Class } & Average Score & Category \\
\hline Control & $56,00 \%$ & Medium \\
\hline Experimental & $63,38 \%$ & High \\
\hline
\end{tabular}

According to Table 1, it is found out that the average of interests from the experimental class is higher than the control class. It is proven by mapping students' interests from each aspect into the interest questionnaire chart, as shown in Figure 1.

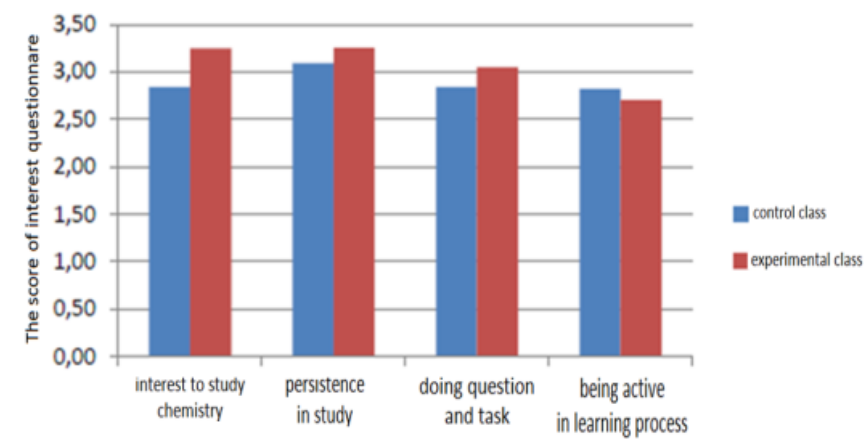

Figure 1. The Average Score Chart of The Interest Questionnaire in Each Aspect. 
The data acquisition result is then analyzed statistically by using the Mann-Whitney test. The test is carried out by using SPSS 20 software. The Mann-Whitney test can be conducted if it has met the prerequisite test: the normality test and the homogeneity test of the interest questionnaire sheet. The result of the analysis can be seen in Table 2 .

Table 2. The Result of MannWhitneyTestonInterest Questionnaire

\begin{tabular}{cc}
\hline Variable & Asymp-sig (2-tailed) \\
\hline Interest Questionnaire & 0,003 \\
\hline
\end{tabular}

Based on the statistical test result, it is obtained that the asymp-sig (2-tailed) value is smaller than 0.05 , that is, 0.003 . This indicates differences in students' learning interests in the experimental class and the control class. It means that the application of the Quantum Teaching and Learning (QTL) model has a good effect on students' interests in learning.

\section{Study of The Effect of The Quantum Teaching and Learning (QTL) Model on Students' Learning Outcomes}

The analysis of students' learning outcomes was obtained by performing a written test in a pretest and post-test for the experimental class and the control class. The result of the average value of both classes can be seen in Table 3 .

Table 3. The Data of Average Value of Learning Outcomes

\begin{tabular}{lcc}
\hline \multicolumn{1}{c}{ Class } & Pre-test & Posttest \\
\hline Control & 35,03 & 60,81 \\
\hline Experimental & 36,19 & 81,13 \\
\hline
\end{tabular}

The data are then analyzed using a parametric statistical test, that is, the Independent-T Test using the SPSS 20 program. The use of this test is performed because the data obtained is usually distributed. The result of the statistical test can be seen in Table 4 below.

Table 4. Data Analysis of the Independent-T Test of Students' Learning Outcomes

\begin{tabular}{lcc}
\hline Variable & Asymp-sig (2-tailed) & $\mathrm{A}$ \\
\hline Pre-test & 0,749 & 0,05 \\
\hline Post-test & 0,000 & 0,05 \\
\hline
\end{tabular}

Based on the statistical test result, the pre-test scores above show that the initial ability of students between the control class and the experimental class does not have a significant difference. It means that both classes have the same ability because it is obtained that the asymp-sig (2-tailed) value is 0.749 higher than the significance level, that is, 0.05 .

The statistical test results on post-test data using the Independent-T Test show a significant difference between the control class and the experimental class. It is proven by the acquisition of a significance value of 0.000 . It is smaller than the significance level, that is, 0.05 . This indicates that using the Quantum Teaching and Learning (QTL) model in the experimental class has a good effect on students' learning outcomes.

Students' achievement in understanding the chemical nomenclature subject in each indicator can be seen after the post-test is carried out. Furthermore, the results can be seen in Figure 2. 


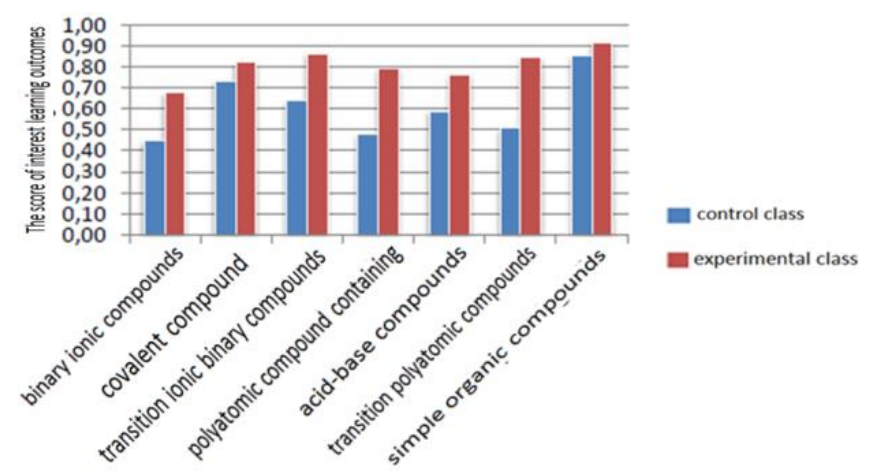

Figure 2. The average chart of cognitive learning outcome test (post-test) in each question indicator

The chart above shows that understanding the chemical nomenclature material for the experimental class is in a higher position than the control class. It shows that the application of the Quantum Teaching and Learning (QTL) model is suitable for assisting students in understanding the subject so that students' learning outcomes are better.

\section{CONCLUSION} obtained.

Based on the research results and analysis that has been conducted, the following conclusions are

1. There is a significant difference between applying the Quantum Teaching and Learning (QTL) and Direct Instruction learning model towards students' interests. This is evidenced by the statistical test results using the Mann-Whitney test, and it is obtained a significance value of $0.003<0.05$. The results of the analysis show that the learning model of Quantum Teaching and Learning (QTL) has a good effect on students' interests.

2. There is a significant difference between applying the Quantum Teaching and Learning (QTL) and Direct Instruction learning model towards students' learning outcomes. This is evidenced by the statistical test results using the Independent T-Test. It is obtained a significance value of $0.000<0.05$. The results of this analysis show that the learning model of Quantum Teaching and Learning (QTL) has a good effect on students' learning outcomes, as is indicated by the average of learning outcomes in the experimental class reaches 80 .

A suggestion that the researcher can give to further researchers is that it is necessary for further research on how to increase student's interest and learning outcomes, especially in chemistry.

\section{REFERENCES}

Aritonang, K. (2008). Minat dan motivasi dalam meningkatkan hasil belajar siswa. Jurnal Pendidikan Penabur, 7(10), 11-21.

Astuti, T. P. (2018). Pengaruh model pembelajaran tandur terhadap kemampuan pemahaman konsep dan penalaran matematis peserta didik. AKSIOMA: Jurnal Program Studi Pendidikan Matematika, 7(2), 20. DOI: 10.24127/ajpm.v7i2.1497.

DePorter, B. \& Hernacki, M. (2005). Quantum teaching. Bandung: Kaifa.

Djalil, M. B. (2015). Paradigma, prinsip, dan aplikasi quantum learning dan quantum teaching dalam pembelajaran. JURNAL LENTERA: Kajian Keagamaan, Keilmuan dan Teknologi, 13(2), 172180. http://ejournal.kopertais4.or.id/mataraman/index.php/lentera/article/view/1260. 
Fayanto, S., Musria, M., Erniwati, E., Sukariasih, L., \& Hunaidah, H. (2019). Implementation of quantum teaching model on improving physics learning outcomes in the cognitive domain at Junior High School. IJIS Edu: Indonesian Journal of Integrated Science Education, 1(2), 131-138. DOI: 10.29300/ijisedu.v1i2.1958.

Haerudin \& Prawiyogi, A. G. (2019). Efektifitas model pembelajaran quantum teaching and learning terhadap motivasi belajar PAI siswa kelas IV. JSD: Jurnal Sekolah Dasar, 4(1), 21-34.

Ismawati, N. \& Hindarto, N. (2011). Penerapan model pembelajaran kooperatif dengan pendekatan struktural two stay two stray untuk meningkatkan hasil belajar siswa kelas X SMA. Jurnal Pendidikan Fisika Indonesia, 7(1), 38-41. DOI: 10.15294/jpfi.v7i1.1067.

Maesaroh, S. (2013). Peranan metode pembelajaran terhadap minat dan prestasi belajar pendidikan agama islam. Jurnal Kependidikan, 1(1), 150-168. DOI: 10.24090/jk.v1i1.536.

Mahirah, B. (2017). Evaluasi belajar peserta didik (Siswa). Jurnal Idaarah, 1(2), 257-267. DOI: 10.24252/idaarah.v1i2.4269.

Manurung, I. W., Mulyani, B., \& Saputro, S. (2013). Pengaruh penggunaan model pembelajaran kooperatif Number Head Together (NHT) dan Learning Together (LT) dengan melihat kemampuan memori siswa terhadap prestasi belajar siswa pada materi tata nama senyawa kimia kelas X SMA Negeri 2 Karanganyar. Jurnal Pendidikan Kimia, 2(4), 24-31. Retrieved from https://jurnal.fkip.uns.ac.id/index.php/kimia/article/view/2755.

Maslukhah, S. A. (2014). Pengembangan permainan tradisional bentengan sebagai media pembelajaran tata nama senyawa di kelas X SMA. Unesa Journal of Chemical Education, 3(3), 207-216. Retrieved from https://jurnalmahasiswa.unesa.ac.id/index.php/journal-of-chemicaleducation/article/view/9767.

Pasaribu, B. Y. (2013). Upaya meningkatkan aktifitas dan hasil belajar kimia pokok bahasan "Tata Nama Senyawa Kimia" melalui model pembelajaran demonstrasi dengan alat peraga kartu tata nama enyawa. Jurnal Formatif, 3(2), 136-144. DOI: 10.30998/formatif.v3i2.120.

Prihatini, E. (2017). Pengaruh metode pembelajaran dan minat belajar terhadap hasil belajar IPA. Jurnal Formatif, 7(2) 171-179. DOI: 10.30998/formatif.v7i2.1831.

Ristiyani, E. \& Bahriah, E. S. (2016). Analisis kesulitan belajar kimia siswa di SMAN X Kota Tangerang Selatan. Jurnal Penelitian dan Pembelajaran IPA, 2(1), 18-29. DOI: 10.30870/jppi.v2i1.431.

Rizka, N. N. \& Pratama, F. A. (2018). Penerapan model pembelajaran quantum teaching melalui strategi tandur untuk meningkatkan kompetensi kognisi siswa. Jurnal Edukasi, 6(1), 183-192. DOI: 10.25157/je.v6i1.1681.

Rumansyah. (2002). Penerapan metode latihan berstruktur dalam meningkatkan pemahaman siswa terhadap konsep persamaan kimia. Jurnal Pendidikan dan Kebudayaan, 8(35), 172.

Saenab, S., Nurhayati, B., Hamka, L., \& Fitri, S. R. (2016). Pembelajaran genetika (Susah) dengan strategi humor (Mudah) apakah mempengaruhi minat siswa? Jurnal Nalar Pendidikan, 4(2), 131136. DOI: 10.26858 /jnp.v4i2.2414.

Sholikhah, O. H. (2017). Implementation of quantum teaching-learning viewed from multiple intelligences in mathematics learning. Proceeding International Seminar of Primary Education, 1, 1-8. Retrieved from http://prosiding.unipma.ac.id/index.php/ISPE/article/view/120. 
Slameto. (2003). Belajar dan faktor-faktor yang mempengaruhinya. Jakarta: Rineka Cipta.

Soleh, A., Pramono, \& Suratno. (2009). Faktor-faktor yang mempengaruhi keberhasilan siswa kelas 2 TMO SMK Texmaco Semarang pada mata diktat service engine dan komponen-komponennya. Jurnal Pendidikan Teknik Mesin, 9(2), 57-64. Retrieved from https://journal.unnes.ac.id/nju/index.php/JPTM/article/view/200.

Sukerthi, D. M., Dantes, N., \& Yudana, I. M. (2013). Pengaruh model pembelajaran tandur dalam pembelajaran geografi terhadap literasi sains dan prestasi belajar siswa Kelas XI IPS SMA Negeri 2 Amlapura. Jurnal Administrasi Pendidikan UNDIKSHA, 4(1), 1-8. DOI: 10.23887/japi.v4i1.964.

Supardi, K. I. \& Putri, I. R. (2010). Pengaruh penggunaan artikel kimia dari internet pada model pembelajaran creative problem solving terhadap hasil belajar kimia siswa SMA. Jurnal Inovasi Pendidikan Kimia, 4(1), $574 \quad$ - 581. Retrieved from https://journal.unnes.ac.id/nju/index.php/JIPK/article/view/1315.

Trisnawati, T., \& Wutsqa, D. (2015). Perbandingan keefektifan quantum teaching dan TGT pada pembelajaran matematika ditinjau dari prestasi dan motivasi. Jurnal Riset Pendidikan Matematika, 2(2), 296 - 307. DOI: 10.21831/jrpm.v2i2.7348.

Wijanarko, Y. (2017). Model pembelajaran make a match untuk pembelajaran IPA yang menyenangkan. Jurnal Taman Cendekia, 1(1), 52-59. DOI: 10.30738/tc.v1i1.1579. 